\title{
Pseudobranchial X-cell pseudotumors in young wild and farmed Atlantic cod Gadus morhua in Iceland
}

\author{
M. Eydal* ${ }^{*}$ Á. Kristmundsson, S. H. Bambir \\ Institute for Experimental Pathology, University of Iceland, Keldur, Vesturlandsvegur, IS-112 Reykjavík, Iceland
}

\begin{abstract}
This study investigated the prevalence of pseudobranchial X-cell pseudotumors in 2 year classes of wild juvenile cod and to a lesser extent in older cod in NW Iceland. The disease was also monitored in farmed wild-caught juvenile cod. The youngest wild cod detected that had X-cell infections were 6.5 to $13.0 \mathrm{~cm}$ in length, with prevalence reaching a maximum level of $7 \%$. The highest prevalence (23\%) was recorded in 18.5 to $27.0 \mathrm{~cm}$ fish. The mean prevalence in older cod (25.0 to $76.0 \mathrm{~cm}$ in length) was $7 \%$ but decreased with increasing age. The mean prevalence of X-cell pseudotumors in farmed juvenile cod was $\leq 1 \%$ during winter rearing in land-based tanks. Higher prevalence ( 2 to $15 \%$ ) was noted in dead and moribund fish. Diseased farmed fish were usually emaciated, and mortality due to the disease was noticeable.
\end{abstract}

KEY WORDS: Pseudotumor $\cdot \mathrm{X}$-cell $\cdot$ Wild $\operatorname{cod} \cdot$ Farmed cod $\cdot$ Prevalence $\cdot$ Disease

\section{INTRODUCTION}

Pseudobranchial tumors, which have more recently been called X-cell disease and are here referred to as pseudobranchial pseudotumors, were first described in Atlantic cod Gadus morhua caught south off Newfoundland, Canada (Peyron \& Thomas 1929). Subsequently, these pseudotumors have been reported in Atlantic cod from the northeastern and northwestern Atlantic Ocean extending from the Barents and North Seas to Icelandic waters, and also from the Baltic Sea and from Canadian waters (Morrison et al. 1979, 1982, Egidius et al. 1981, Watermann \& Dethlefsen 1982, Watermann et al. 1982, Dethlefsen et al. 1996, Mellergaard \& Lang 1999). Pseudotumors in the pseudobranchial organ have also been described from the Pacific cod Gadus macrocephalus (Takahashi 1929, Stich et al. 1976, McCain et al. 1978, 1979).

Lesions that were historically referred to as pseudobranchial tumors in the Atlantic cod Gadus morhua are now more accurately referred to as pseudobranchial $\mathrm{X}$-cell pseudotumors, since the causative agent is a parasite. The so-called X-cells have been found in these non-neoplastic growths of pseudotumors in various organs of many benthic fish species all over the world, including the skin and gills of flatfishes (family Pleuronectidae), and their morphology appears to be relatively uniform (Franklin et al. 1993, Miwa et al. 2004, Freeman et al. 2009). The identity of these Xcells has been speculative for many years but they are now recognized as being parasitic protozoans, although their actual systematic position remains unknown (Miwa et al. 2004, Freeman et al. 2009).

The aims of the present study were to (1) survey the presence of pseudobranchial X-cell pseudotumors in wild juvenile Atlantic cod in Icelandic waters, (2) evaluate the progression of infection prevalence with age, and (3) monitor the disease in farmed juvenile cod of wild origin in Iceland. 


\section{MATERIALS AND METHODS}

Wild cod. During the years 1998 to 2000,572 juvenile cod $(0+$ and $1+$ age groups; total length 3.5 to $27.0 \mathrm{~cm}, \sim 4$ to $22 \mathrm{mo}$ old) belonging to year classes 1998 and 1999 were sampled at fixed intervals during the first $2 \mathrm{yr}$ of life. The fish were caught within depths of 35 to $135 \mathrm{~m}$ with a traditional inshore shrimp trawler at various locations throughout the fjord Isafjardardjup in NW Iceland and screened for the presence of pseudobranchial X-cell pseudotumors. In addition, 199 older cod that were $2 \mathrm{yr}$ and older were sampled in Isafjardardjup in October 2000 and examined for these lesions (Fig. 1, Table 1). All fish were weighed and their length measured, except that only length was measured for cod that were 2 yr and older. Fish were examined either histologically or macroscopically. For histological examinations, whole bilateral pseudobranchs were fixed in $10 \%$ buffered formalin, embedded in paraffin wax and sectioned according to routine histological protocols. The $5 \mu \mathrm{m}$ sections were stained with Giemsa stain and examined for histopathological changes. For macroscopic observations, the opercula were spread out or removed for visual examination of both pseudobranchial organs. Juvenile cod that were 4 to 6 mo old ( 3.5 to $13.0 \mathrm{~cm}$ total length) were examined using histological techniques. Cod that were 10 mo old (8.0 to $15.5 \mathrm{~cm}$ total length) were examined either using histological techniques $(\mathrm{n}=90)$ or macroscopically $(n=20)$, while all larger cod were examined using the latter method.

Farmed cod. Wild cod juveniles in their first year $(\sim 2 \mathrm{~g})$ have annually been caught using the traditional shrimp trawler in coastal waters of the fjord Isafjardardjup at depths ranging from 7 to $70 \mathrm{~m}$, during August to October. Three year classes (2002, 2003 and 2004) were specifically examined in the present study.

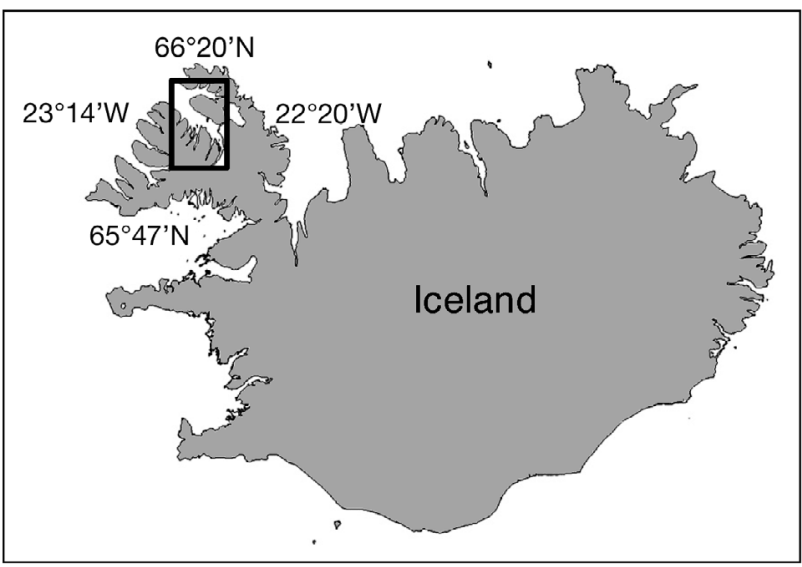

Fig. 1. Sampling area for Atlantic cod Gadus morhua in the fjord Isafjardardjupfjord, NW Iceland (within the rectangle)
Table 1. Gadus morhua. Number of wild cod examined at each age in Icelandic waters

\begin{tabular}{|lcccc|}
\hline \multirow{2}{*}{$\begin{array}{l}\text { Sampling } \\
\text { date }\end{array}$} & $\begin{array}{c}\text { Age at } \\
\text { sampling }(\mathrm{mo})\end{array}$ & $\begin{array}{c}\text { Total length } \\
(\mathrm{cm})\end{array}$ & \multicolumn{2}{c|}{ Year class } \\
Aug 1998/1999 & 4 & $3.5-7.5$ & 59 & 1999 \\
Oct 1998/1999 & 6 & $6.5-13.0$ & 60 & 59 \\
Feb 1999/2000 & 10 & $8.0-15.5$ & 60 & 50 \\
Oct 1999/2000 & 18 & $15.5-25.0$ & 102 & 71 \\
Feb 2000 & 22 & $18.5-27.0$ & 0 & 52 \\
Oct 2000 & $30+$ & $25.0-76.0$ & $199^{\mathrm{a}}$ & \\
ancludes fish in earlier year classes & & & \\
\hline
\end{tabular}

Total catches were 65000 juveniles in 2002, 730000 in 2003 and 1000000 in 2004. The fish were taken to a nearby shore-based farming facility at Nauteyri, and reared in tanks for 8 to $9 \mathrm{mo}$, from autumn to spring. Tank volume ranged from 2 to $108 \mathrm{~m}^{3}$ and biomass was comparable in all tanks, i.e. 30 to $50 \mathrm{~kg} \mathrm{~m}^{-3}$. Subsequently, at $\sim 80$ to $200 \mathrm{~g}$, the fish were transported to sea cages for further rearing. In addition, 6000 disease-free hatchery raised juveniles (17 $\mathrm{g}$ mean weight) from the hatchery station of the Marine Research Institute (Stadur, Iceland) were reared in cohabitation with 5200 wild fish of year class 2002, and divided into two $50 \mathrm{~m}^{3}$ tanks. Wild cod and cod of hatchery origin of other year classes were reared in separate tanks. In cohabitation, the fish of hatchery origin were either fin clipped (posterior dorsal fin) or tagged with plastic-tipped dart tags to distinguish them from the wild fish. In addition, they were noticeably larger than the wild fish.

Salinity and seawater temperature in the tanks were recorded regularly throughout the examination period. Seawater was pumped into the tanks from a depth of $\sim 30 \mathrm{~m}$ from the open sea. Temperature in the tanks was controlled by an inflow of geothermal freshwater and maintained at $\sim 8^{\circ} \mathrm{C}$. Salinity ranged from 25 to 35 during the period of tank rearing. In the sea cages, annual temperature at 1 to $3 \mathrm{~m}$ depth varied from $\sim 1$ to $14^{\circ} \mathrm{C}$.

The prevalence of pseudobranchial X-cell pseudotumors in the young cod in tanks was evaluated by (1) random sampling and macroscopic examination of fish 3 to $5 \times$ each winter, (2) macroscopic examination of dead and moribund/emaciated fish, including one examination of year class 2007 fish, with histological sampling to verify the presence of X-cells, and (3) visual inspection of fish (in the tanks) with large pseudotumors, which become clearly noticeable due to their protruding opercula. Using this method, we monitored the time when fish became diseased during the rearing period and obtained information about the progression of the disease. Histological and macroscopic examinations were performed as described for wild cod.

The numbers and ages of fish that were sampled randomly and examined during rearing in land-based 


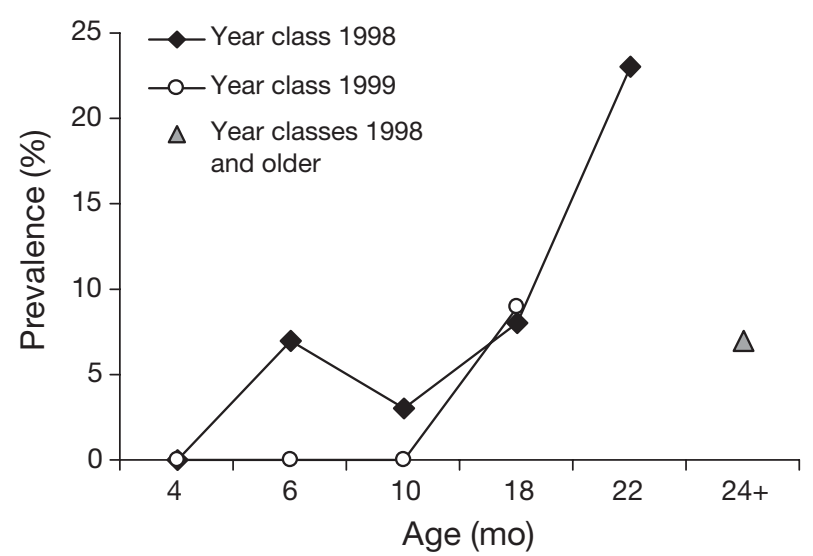

Fig. 2. Gadus morhua. Prevalence of pseudobranchial X-cell pseudotumors in wild Atlantic cod from Isafjardardjup in NW Iceland during 1998 to 2000. Histological examination was done on 4 to 6 mo old fish as well as on $82 \%$ of 10 mo old fish. The rest of the 10 mo old fish and all older fish were examined macroscopically

tanks, also including cod of year class 2006 that were examined in January 2007, are given in Table 2. After transport to sea cages, in May to June each year, fish were sampled after 7,10 and 13 mo in sea cages and examined macroscopically for the presence of typical X-cell pseudotumors. Samples included a total of 275 cod of wild origin, 280 fish of hatchery origin and 65 emaciated fish of both origins, belonging to year classes 2002 and 2003.

\section{RESULTS}

\section{Wild cod}

Some difference in the prevalence of pseudobranchial X-cell pseudotumors was observed between the 2 main year classes under study (Fig. 2). In juveniles of year class 1998, pseudobranchial infection was first detected in cod that were 6.5 to $13.0 \mathrm{~cm}$ in length $(6 \mathrm{mo}$ old) with a prevalence of $7 \%$. Pseudotumors were found on all the following sampling dates, with the highest prevalence $(23 \%)$ being recorded in cod that were 18.5 to $27.0 \mathrm{~cm}$ in length (22 mo old). In 10 mo old cod, pseudotumors were identified only in fish that were examined using histological methods (in 3 out of $90 \mathrm{cod})$, but not in 20 fish that were examined macroscopically. In young cod of the year class 1999, pseudotumors were only seen in 18 mo old cod with a prevalence of $9 \%$, but larger fish of this year class were not studied.

In the oldest group ( 2 yr and older), the mean prevalence of fish with X-cell pseudotumors was $7 \%$. The prevalence in this group decreased with increasing cod length, with prevalence being 8 and $5 \%$ in the length groups 25 to $35 \mathrm{~cm}(\mathrm{n}=99)$ and 36 to $76 \mathrm{~cm}(\mathrm{n}=$ 100), respectively. The prevalence in the largest cod among these (40 to $76 \mathrm{~cm}, \mathrm{n}=73$ ) was only $1 \%$. In this group of cod ( $2 \mathrm{yr}$ and older), $85 \%$ of the affected specimens had bilateral pseudotumors.

Our data did not reveal any clear evidence that affected wild cod were undersized or emaciated, within either young or older age groups.

\section{Farmed cod}

The prevalence of pseudobranchial X-cell pseudotumors in randomly sampled juvenile fish in land-based tanks ranged from 0 to $1 \%$ (Table 2). Pseudotumors were first found in January, after $\sim 4$ mo rearing, followed by fluctuating prevalence. Just prior to transport to sea cages in June, the prevalence was 0 to $0.2 \%$.

The prevalence in emaciated/moribund fish ranged from 3.3\% (in March; $\mathrm{n}=30$ ) to $15 \%$ (in December; $\mathrm{n}=$ $20)$. A prevalence of $2 \%(n=100)$ was observed in dead fish in December, dead fish showing characteristic X-cells in histological sections from pseudobranchial pseudotumors.

Table 2. Gadus morhua. Prevalence (\%) of pseudobranchial X-cell pseudotumors in farmed young cod of wild origin during rearing in land-based tanks in Iceland (random sampling). $\mathrm{n}$ : number of fish examined

\begin{tabular}{|c|c|c|c|c|c|c|c|c|c|}
\hline \multirow[t]{2}{*}{$\begin{array}{l}\text { Sampling } \\
\text { month }\end{array}$} & \multirow{2}{*}{$\begin{array}{c}\text { Age at } \\
\text { sampling } \\
\text { (mo) }\end{array}$} & & & & & Year class- & & \multicolumn{2}{|c|}{2006} \\
\hline & & Prev. & $\mathrm{n}$ & Prev. & $\mathrm{n}$ & Prev. & $\mathrm{n}$ & Prev. & $\mathrm{n}$ \\
\hline Sep & 5 & - & & 0 & 84 & - & & - & \\
\hline Oct & 6 & - & & - & & 0 & 30 & - & \\
\hline Nov & 7 & - & & 0 & 268 & - & & - & \\
\hline Dec & 8 & 0 & 30 & - & & 0 & 34 & - & \\
\hline Jan & 9 & - & & 0 & 40 & - & & 0.5 & 1000 \\
\hline Feb & 10 & 0 & 32 & - & & - & & - & \\
\hline Mar-Apr & $11-12$ & 1.0 & 209 & 0 & 230 & 0 & 60 & - & \\
\hline Jun & 14 & 0.2 & 520 & 0 & 330 & - & & - & \\
\hline
\end{tabular}


Visual inspection revealed juvenile cod with protruding opercula due to large pseudobranchial X-cell pseudotumors (Fig. 3) after 2 to 3 mo rearing (November to December). This is 1 to 2 mo earlier than in fish that were found to be affected by pseudotumors by random sampling. This occurred during all 3 winters under study. In the following weeks, the numbers of visibly diseased fish increased; however, by the end of the 8 to 9 mo period of tank-rearing, infected fish were rarely seen. Cod juveniles with obvious external signs of pseudobranchial pseudotumors that were seen swimming at the surface were typically smaller and emaciated compared to other fish in the tanks.

Pseudobranchial X-cell pseudotumors were not found in wild farmed cod following transport to sea cages. Pseudotumors were never seen in cod of hatchery origin, either in land-based tanks or following transport to sea cages.

\section{DISCUSSION}

The present study revealed a relatively high prevalence of the typical pseudotumors that are produced by infection with X-cells of the pseudobranchs of juvenile wild cod in Icelandic waters. In contrast, previous studies have reported a low prevalence of pseudobranchial $\mathrm{X}$-cell pseudotumors in wild Atlantic cod (Morrison et al. 1982, Watermann et al. 1982, Mellergaard \& Lang 1999). The prevalence of infection in wild cod of 6 mo

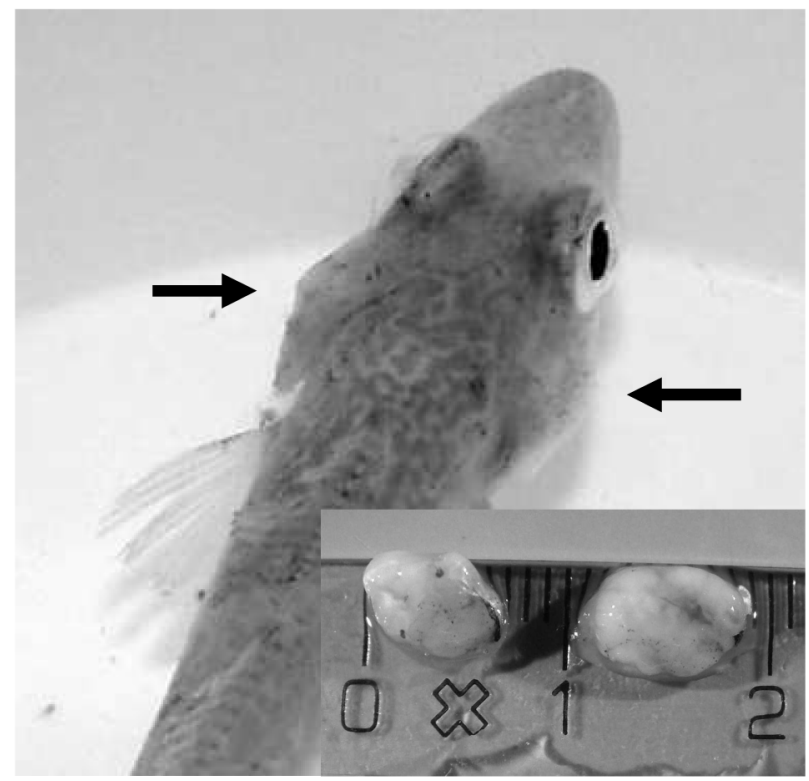

Fig. 3. Gadus morhua. Opercula (arrows) protruding from bilateral pseudobranchial X-cell pseudotumor swellings in a juvenile farmed cod in Iceland (fish length: $10 \mathrm{~cm}$ ). Insert: Pseudotumors after excision from another juvenile (cod length: $12 \mathrm{~cm}$; length of pseudotumors: 0.8 and $0.9 \mathrm{~cm}$ ) age (6.5 to $13.0 \mathrm{~cm}$ length) from Icelandic waters had reached $7 \%$ in 1 of the 2 year classes studied (Fig. 2.) This is apparently the youngest cod ever reported to have X-cell disease in the pseudobranch. Prevalence reached a peak of $23 \%$ in cod of 18.5 to $27.0 \mathrm{~cm}$ length, whereas the mean prevalence was 7 and $1 \%$ in older cod and in the largest fish (40 to $76 \mathrm{~cm}$ ), respectively. A comparable trend was reported in Pacific cod Gadus macrocephalus off the coast of British Colombia, Canada, by Stich et al. (1976), who observed a prevalence of pseudobranchial X-cell pseudotumors of up to $100 \%$ in younger fish (39 to $44 \mathrm{~cm}$ length) from certain locations. Their studies showed decreased prevalence with increasing fish length, with prevalence dropping to $0 \%$ in the largest fish examined (i.e. $>62$ and $>76 \mathrm{~cm}$ fish at 2 separate locations). Morrison et al. (1982) reported a higher prevalence in smaller than in larger Atlantic cod. Dethlefsen et al. (1996) reported that prevalence varied from 0 to $4.6 \%$ in cod that were $<40 \mathrm{~cm}$ in length from the North Sea, compared to 1.7 to $8.0 \%$ in 25 to $100 \mathrm{~cm}$ fish at stations off the southeast, east and northeast coast of Iceland. Affected fish in Icelandic waters (Dethlefsen et al. 1996) were significantly smaller than unaffected groups at comparable ages, in agreement with the findings of McCain et al. (1979) in walleye pollock with pseudobranchial X-cell pseudotumors. Watermann et al. (1982) have shown that undersized fish among young Atlantic cod from the North and Baltic Seas had the highest prevalence of the disease, and Watermann \& Dethlefsen (1982) found that cod in these waters were generally in good condition apart from the smallest fish in each year class, a few of which were emaciated. No affected fish were found by Dethlefsen et al. (1996) in nearshore waters southwest of Iceland, in deep waters southeast off Iceland or off the Faroe and the Shetland Islands. In cod from the Baltic Sea, the mean prevalence of pseudotumors in 3241 fish was $0.2 \%$, ranging from 0 to $0.4 \%$ in $<22 \mathrm{~cm} \mathrm{cod}, 0$ to $2.2 \%$ in 22 to $34 \mathrm{~cm} \mathrm{cod} \mathrm{and}$ 0 to $1.5 \%$ in $>35 \mathrm{~cm}$ fish (Mellergaard \& Lang 1999). A low prevalence of pseudotumors, ranging from 0.4 to $1.7 \%$, was reported by Egidius et al. (1981) in $8850 \mathrm{cod}$ (20 to $90 \mathrm{~cm}$ length range) from the Barents Sea.

We emphasize that the presence of pseudobranchial $\mathrm{X}$-cell pseudotumors in the older groups of wild cod in our study was ascertained macroscopically and we may therefore have underestimated the true prevalence. Conversely, histological methods that were applied to the younger fish could detect an early stage of X-cell infection and might therefore more accurately represent actual prevalence (Fig. 2).

Cod farming in Iceland is still in an early phase of development. In the present study, we monitored infectious diseases in wild juvenile cod that were caught in the fall for rearing in a land-based farm 
over winter, with subsequent transport to sea cages in the following spring. Our studies on wild cod juveniles revealed 0 to $7 \%$ prevalence of infection of pseudobranchial glands by X-cells in 6 mo old cod. This is an early stage of infection that is detectable only by histological methods. It is, therefore, clear that a proportion of the wild juveniles were already infected at the time of capture and transport to the rearing environment. The results showed that after $\sim 3$ mo of rearing, pseudobranchial X-cell pseudotumors became evident by gross visual examination; the mean prevalence was low $(\leq 1 \%$, Table 2$)$, but higher ( 2 to $15 \%$ ) in dead and moribund fish. Infected fish gradually became emaciated, and a large proportion of them evidently died. Stress factors related to the intensive farming conditions might have enhanced the progress and severity of the disease. Although the prevalence found by random sampling was very low, fish affected by pseudotumors were visible and could easily be detected due to their protruding opercula (Fig. 3), in all tanks during the latter part of landbased rearing, except that no affected juveniles of hatchery origin were seen.

Our data is inadequate to speculate on the potential effects of pseudobranchial X-cell pseudotumors on the growth or survival of wild juvenile cod. In general, no obvious differences in body condition between affected and unaffected cod were noticed. However, it is interesting to note that the mean prevalence of affected fish in the $2 \mathrm{yr}$ and older group was lower than that in cod at 22 mo of age, and the prevalence was lowest $(1 \%)$ in the oldest fish in this group. This decline in prevalence might suggest mortality caused by the infection. However, it is evident that there was a high prevalence of pseudotumors in dead and moribund/emaciated wild-caught cod during rearing in land-based tanks over winter. After being transferred to sea cages, pseudotumors were not detected, which might further support the assumption that most infected fish died during the tank-rearing phase.

The mode of transmission of $\mathrm{X}$-cell disease still remains enigmatic. However, the results from the present studies on farmed cod in Iceland indicate that transmission is not direct between fish. This is supported by the fact that X-cell disease-free cod of hatchery origin did not develop any macroscopically visible signs of pseudobranchial X-cell pseudotumors when reared together with wild-infected fish either during one winter in land-based tanks or in subsequent rearing in sea cages. No reports exist where attempts have been made to transmit the X-cell organism from affected cod to disease-free cod. Attempts to transmit $\mathrm{X}$-cells from pseudotumors found in the skin of fish of the Pleuronectidae family using in vivo and in vitro trials were not successful (Wellings et al. 1976).
The reason for the differences in prevalence of the disease between fish of different ages and between fish from different waters and different depths is not known. It could be related to the mode of transmission of the X-cell organism. If the life cycle of the X-cell involves other stages of the organism, which perhaps require intermediate or transport hosts, acquiring the disease could then be dependent on the geographical and depth distribution of the additional host or hosts involved.

Additional studies to elucidate the mode of transmission and the impact of $\mathrm{X}$-cell disease on condition and mortality of affected cod, particularly in juveniles both in the wild environment and in cod farms, are needed to address these issues.

Acknowledgements. We acknowledge grants from The Icelandic Research Council, The Icelandic Republic Fund and AVS R\&D Fund of the Ministry of Fisheries in Iceland. We thank personnel from the Marine Research Institute, Hradfrystihusid Gunnvör ltd. and Háafell ehf. in Iceland for their cooperation.

\section{LITERATURE CITED}

Dethlefsen V, Lang T, Damm U (1996) X-cell disease in cod Gadus morhua from the North Sea and Icelandic waters. Dis Aquat Org 25:95-106

> Egidius EC, Johannessen JV, Lange E (1981) Pseudobranchial tumors in Atlantic cod, Gadus morhua L., from the Barents Sea. J Fish Dis 4:527-532

Franklin CE, McKenzie JC, Davison W, Carey PW (1993) Xcell gill disease obliterates the lamellar blood-supply in the Antarctic teleost, Pagothenia borchgreviniki (Boulenger 1902). J Fish Dis 16:249-254

Freeman M, Kristmundsson A, Eydal M, Yoshimizu M, Ogawa K (2009) X-cell parasites: a potential identity. Diseases of fish and shellfish. 14th EAFP 2009 Int Conf, Prague, 14-19 September 2009, Abstract book. HALAMA Publishing House, České Budějovice, p 111

McCain BB, Myers MS, Gronlund WD, Wellings SR, Alpers CE (1978) The frequency, distribution, and pathology of three diseases of demersal fishes in the Bering Sea. J Fish Biol 12:267-276

McCain BB, Gronlund WD, Myers MS, Wellings SR (1979) Tumors and microbial diseases of marine fishes in Alaskan waters. J Fish Dis 2:111-130

Mellergaard S, Lang T (1999) Diseases and parasites of Baltic cod (Gadus morhua) from the Mecklenburg Bight to the Estonian coast. ICES J Mar Sci 56:164-168

Miwa S, Nakayasu C, Kamaishi T, Yoshiura Y (2004) X-cells in fish pseudotumors are parasitic protozoans. Dis Aquat Org 58:165-170

Morrison CM, Appy RG, Shum G, Annand C, Odense P (1979). Histology and the incidence of pseudobranch tumours in Atlantic cod (Gadus morhua) in Halifax Harbour. ICES CM E:31

Morrison CM, Shum G, Appy RG, Annand C, Odense P (1982) Histology and prevalence of X-cell lesions in Atlantic cod (Gadus morhua). Can J Fish Aquat Sci 39:1519-1530

Peyron A, Thomas L (1929) Contribution à l'étude des tumeurs du revêtement branchial chez les poissons. Bull 
Assoc Fr Etud Cancer 18:825-827

Stich HF, Acton AB, Forrester CR (1976) Fish tumors and sublethal effects of pollutants. J Fish Res Board Can 33:19932001

Takahashi K (1929) Studie über die Fishgeschwulste. Z Krebsforsch 29:1-73

- Watermann B, Dethlefsen V (1982) Histology of pseudobranchial tumours in Atlantic cod (Gadus morhua) from the North Sea and the Baltic Sea. Helgol Meersunters

Editorial responsibility: Thomas Lang,

Cuxhaven, Germany
35:231-242

Watermann B, Dethlefsen V, Hoppenheit M (1982) Epidemiology of pseudobranchial tumours in Atlantic cod (Gadus morhua) from the North Sea and the Baltic Sea. Helgol Meersunters 35:425-437

Wellings SR, McCain BB, Miller BS (1976) Epidermal papillomas in Pleuronectidae of Puget Sound, Washington: review of the current status of the problem. Prog Exp Tumor Res 20:55-74

Submitted: October 14, 2009; Accepted: May 27, 2010 Proofs received from author(s): July 5, 2010 